\title{
Aerial Application of Herbicides for Control of Sand Sagebrush ${ }^{1}$
}

\section{R. W. BOVEY 2 \\ Crops Research Division, ARS, USDA, Dept. of Range and Forestry, Texas $A \& M$ University, College Station, Texas.}

\section{Highlight}

Single aerial applications of 2,4-D; 2,4,5-T; and a 1:1 mixture of the two gave excellent control of sand sagebrush at some locations in western Nebraska. Repeat applications were necessary for best results to kill regrowth the following year. Silvex consistently gave excellent control from a single application.

Sand sagebrush (Artemisia filifolia Torr.) is a woody shrub, 30 to $150 \mathrm{~cm}$. tall with freely branching stems occurring on dry plains of Nebraska, Wyoming, and south to Mexico. Klingman (1962) indicated the total acreage infested by this shrub in the continental United States is estimated at 96 million acres. Shafer (1955) reported at least 100,000 acres in western $\mathrm{Ne}$ braska almost useless for grazing

1 Published with the approval of the Director as Paper No. 1463, Journal Series, Nebraska Agricultural Experiment Station. This research was partly financed by the Nebraska Department of Aeronautics, Lincoln.

${ }^{2}$ Formerly Instructor in Agronomy, Dept. of Agronomy, Nebraska Agricultural Expt. Sta., Lincoln, Nebraska. because of sand sagebrush (Figure 1). McIlvain et al. (1955) conducted extensive control experiments of the species in Oklahoma, showing that one proper application of 2,4-D can kill three-fourths of the sagebrush on infested lands. Subsequent forage and beef production can be increased from 50 to 75 percent. The most effective spray solution was $1 \mathrm{lb} / \mathrm{A}$ of the ester form of 2,4-D in three gallons per acre (gpa) diesel oil or a 2:1 water: oil emulsion.

Shafer (1951) conducted preliminary aerial application control studies on sand sagebrush in 1949, at Benkelman, Nebraska. Treatment with 2,4-D for two consecutive years gave best results. Average percentage kill one year after a single application was 60 percent as compared to 96 percent one year after two consecutive years of treatment. Diesel oil was considered the most effective carrier. Optimum treatment time of sand sagebrush usually occurs during June depending on the amount and rate of new growth.

The studies reported here were conducted to determine the

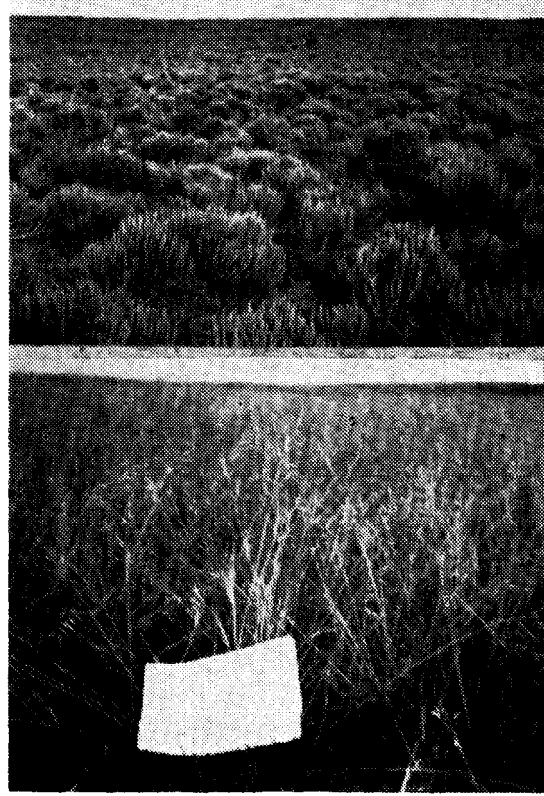

Figure 1. Top-Dense stand of sand sagebrush near Haigler, Nebraska. Forage production is greatly reduced. Aircraft applications of herbicides are ideal for such large acreages. Bottom-Area at Alliance, Nebraska, aerially treated June, 1961 and 1962, with one lb./A 2,4-D in No. 2 diesel oil at 5 gpa. Ungrazed luxuriant growth of needle and thread released by removal of sand sagebrush. Photograph June, 1963.

most economical and effective herbicide and/or herbicides, carriers and spray volumes for sand sagebrush control by aircraft.

\section{Materials and Methods}

Sand sagebrush control studies were initiated in 1960 at Alliance and Haigler, Nebraska, on a Val- 
entine fine sandy loam and a Dundy loamy fine sand, respectively. The mean annual temperature is $48.2^{\circ} \mathrm{F}$. with an annual precipitation of 15.0 inches at Alliance. At Haigler the mean annual temperature is $53.8^{\circ} \mathrm{F}$. with a yearly precipitation of 16.2 inches. The majority of the precipitation occurs in the spring and summer months at both locations. The predominant native grass at the Alliance location is needle and thread (Stipa comata Trin. \& Rupr.). At the Haigler site the main native grasses are as follows in order of predominance: blue grama (Bouteloua gracilis (H. B. K.) Lag.), prairie sandreed grass (Calamovilfa longifolia (Hook) Scribn.) and little bluestem (Andropogon scoparius Michx.).

Aerial application equipment consisted of a Piper Super Cub with a modified spray dispersal system. Spray booms were relocated to give uniform spray coverage and drift control. A total of 37 Whirljet type nozzles were placed at desired locations on the streamlined boom. Constant output by the spray solution pump was accomplished by a hydraulic drive system (Shafer, 1960).

Herbicide treatments were made when sand sagebrush had attained 6 to 10 inches of new growth. The herbicides used were the propylene glycol butyl ether (PGBE) esters of 2,4-D, 2, 4, 5-T, 2-(2, 4, 5-trichlorophenoxy) propionic acid (silvex) and a 1:1 mixture of 2,4-D and 2,4,5-T.

In the first experiment, aerial spray applications were made on June 17, 1960, at Alliance, and June 24, 1960, at Haigler. At Alliance, the 2,4-D treatments were applied at $1 / 2$, 1 , and $2 \mathrm{lb} / \mathrm{A}$. The 2,4,5-T, 2,4-D and 2,4,5-T mixture and silvex were applied at $2 \mathrm{lb} / \mathrm{A}$. At Haigler, 2,4-D was applied at $1 / 2,1$, and $2 \mathrm{lb} / \mathrm{A}$, $2,4,5-\mathrm{T}$ at $1 / 2,1$, and $2 \mathrm{lb} / \mathrm{A}$, and the 2,4-D and 2,4,5-T mixture at $2 \mathrm{lb} / \mathrm{A}$. Repeat applications were made on June 20,1961, at Alliance, and June 21, 1961, at Haigler. Retreatment consisted of original herbicides and rates as applied in 1960 superimposed on $1 / 2$ of the original plots. Therefore, the retreated plots were 99 by 220 feet in area.

Leaf kill was determined three months after treatment on thirty plants randomly selected in each plot. Control ratings were made on the basis of 0 to 10 , with from no leaf kill to complete kill. These values were converted to percentages. Regrowth was determined by evaluating 30 plants at random in each plot during June, one, two, and three years after initial herbicide applications. Percentage regrowth, as used in this paper, is the reciprocal of percentage kill. Each plant evaluated was considered alive if any regrowth was present and dead if regrowth was absent. Visual estimates of control, based on total top kill (leaf and stem) were made in June, 1963 , at the conclusion of the experiment to supplement other counts.

Additional experiments were established on June 20, 1961, at Alliance and June 18, 1962, at Haigler to study the effects of herbicide carriers and spray volumes on sand sagebrush control.

Number 2 diesel fuel, water, and water plus a surfactant (Multifilm $\mathrm{X}-77$ ) were the three carriers used. Spray volumes consisted of 2 and 5 gallons per acre. One $\mathrm{lb} / \mathrm{A}$ of the PGBE esters of 2,4-D was used with all carrier-spray volume combinations. Each plot was two flight strips wide, each strip being 33 feet wide and 330 feet long. Each treatment was replicated. Percentage regrowth of sand sagebrush was determined by randomly selecting 20 plants in each plot and designating as dead or alive one year after the initial treatment and one year after retreatment. Repeat applications were made at Alliance in midJune, 1962, superimposing identical treatments on the original plots after kill evaluations were made. Retreatments were not made on the Haigler site. Evaluations were also determined by visual estimation of top kill in June, 1963.

Aerial control of sand sagebrush was also studied on a dunesand soil at Angora, Nebraska, near Alliance. Two experiments at this location were conducted primarily for the control of Yucca (Yucca glauca Nutt.) but sand sagebrush occurred on all plots. Studies initiated on June 17, 1960, consisted of one acre plots with retreatment of one-half the original plot on June 20, 1961. One, two and four lb/A of silvex was applied. On June 19, 1961, a carrier-spray volume study was initiated for Yucca control. The treatments consisted of diesel fuel, water alone, and water plus surfactant. Silvex at $2 \mathrm{lb} / \mathrm{A}$ was applied in combination with each carrier at spray volumes of 2 and 5 gpa. Repeat applications were made on June 18, 1962. Percentage regrowth was determined by counting all sand sagebrush plants in each plot and designating as dead or alive. Control evaluations were made three months, one, two, and three years after original application in the case of the study initiated in 1960, and one and two years in the 1961 study.

\section{Results and Discussion}

Excellent top kill can be obtained with a single application of 2,4-D, 2,4,5-T or silvex. However, regrowth may occur the year after a single application. The amount of regrowth depends on time of application, stage of growth, environmental conditions, herbicides and dosage. The time of application was considered optimum in these studies since they were made when there was adequate soil moisture. Plants were in full leaf and growing rapidly.

In the first experiment, considerable regrowth took place the year following initial application at the Alliance and Haigler locations (Table 1 top). In general, top kill of sand sagebrush was better at Haigler three months after treatment than at Alliance. However, the amount of regrowth at Haigler was much greater one year after a single application. Two years after single application, increase in regrowth at Alliance was considerable in all but the 2,4,5-T and silvex plots while at Haigler, 2,4-D at $1 \mathrm{lb} / \mathrm{A}$, the $1: 1$ mixture of 2,4-D and 2,4,5-T at $1 \mathrm{lb} / \mathrm{A}$ each and 2,4,5-T at $1 \mathrm{lb} /$ showed a decrease in regrowth. Percentage regrowth did not markedly change from two to three years after a single application of chemical at either location. 
Table 1. Initial leaf kill and subsequent regrowth of sand sagebrush after single and repeat applications of PGBE ester formulations of 2,4-D, 2,4,5-T, 2,4-D plus 2,4,5-T and silvex in diesel oil at $5 \mathrm{gpa}$.

Time after application

\begin{tabular}{|c|c|c|c|c|c|c|c|}
\hline \multirow{4}{*}{$\begin{array}{l}\text { Location } \\
\text { and } \\
\text { herbicide }\end{array}$} & \multirow[b]{4}{*}{ Rate } & \multirow{2}{*}{\multicolumn{4}{|c|}{ Single }} & \multirow{3}{*}{\multicolumn{2}{|c|}{$\begin{array}{c}\text { Repeat } \\
\text { Regrowth }\end{array}$}} \\
\hline & & & & & & & \\
\hline & & Leaf kill & \multicolumn{3}{|c|}{ Regrowth ${ }^{1}$} & & \\
\hline & & $3 \mathrm{mo}$. & $1 \mathrm{yr}$. & $2 \mathrm{yr}$. & 3 yr. & $1 \mathrm{yr}$. & $2 \mathrm{yr}$. \\
\hline & $(\mathrm{Lb} / \mathrm{A})$ & -- & $-\cdots$ & $-(\mathrm{Pe}$ & ent) - & -- & -- \\
\hline \multicolumn{8}{|l|}{ Alliance } \\
\hline 2,4-D & $1 / 2$ & 57 & 45 & 80 & 83 & 17 & 50 \\
\hline $2,4-\mathrm{D}$ & 1 & 86 & 35 & 70 & 50 & 13 & 7 \\
\hline 2,4-D & 2 & 96 & 25 & 60 & 60 & 7 & 3 \\
\hline $2,4-\mathrm{D}+2,4,5-\mathrm{T}$ & $1+1$ & 97 & 20 & 63 & 40 & 3 & 0 \\
\hline $2,5,5-\mathrm{T}$ & 2 & 98 & 40 & 53 & 60 & 0 & 0 \\
\hline Silvex & 2 & 99 & 22 & 20 & 23 & 7 & 3 \\
\hline \multicolumn{8}{|l|}{ Haigler } \\
\hline 2,4-D & $1 / 2$ & 90 & 72 & 73 & 43 & $10^{2}$ & 0 \\
\hline $2,4-D$ & 1 & 100 & 57 & 23 & 27 & 0 & 0 \\
\hline $2,4-D$ & 2 & 100 & 55 & 60 & 50 & 0 & 0 \\
\hline $2,4-\mathrm{D}+2,4,5-\mathrm{T}$ & $1+1$ & 100 & 67 & 57 & 33 & 0 & 0 \\
\hline $2,4,5-\mathrm{T}$ & $1 / 2$ & 100 & 62 & 67 & 80 & 0 & 0 \\
\hline $2,4,5-\mathrm{T}$ & 1 & 100 & 57 & 53 & 60 & 0 & 0 \\
\hline $2,4,5-\mathrm{T}$ & 2 & 100 & 52 & 70 & 70 & 0 & 0 \\
\hline
\end{tabular}

1Percentage kill is the inverse of percentage regrowth; it can be derived by subtracting percentage regrowth from 100.

2 The $1 / 2 \mathrm{lb} / \mathrm{A} 2,4-\mathrm{D}$ treatment at Haigler was retreated with $1 \mathrm{lb} / \mathrm{A}$.

Evaluations one year after initial treatment indicated retreatment was necessary for best control of sand sagebrush (Table 1). At Alliance one-half $\mathrm{lb} / \mathrm{A}$ of 2,4-D showed 17 and 50 percent regrowth for one and two years, respectively, after repeat applications. The remaining treatments showed less regrowth. At

Table 2. Sand sagebrush control based on top kill 3 years after original aerial application on plots with single and repeat treatments of PGBE ester of 2,4-D, 2,4,5-T, $2,4-D$ plus $2,4,5-T$, and silvex in diesel oil at 5 gpa.

\begin{tabular}{|c|c|c|}
\hline Location and & & Treatment \\
\hline herbicide & $\mathrm{Lb} / \mathrm{A}$ & Single Repeat \\
\hline
\end{tabular}

Alliance

(Percent)

$\begin{array}{lccr}\text { 2,4-D } & 1 / 2 & 50 & 70 \\ 2,4-\mathrm{D} & 1 & 60 & 95 \\ \text { 2,4-D } & 2 & 70 & 99 \\ 2,4-\mathrm{D}+2,4,5-\mathrm{T} & 1+1 & 70 & 100 \\ 2,4,5-\mathrm{T} & 2 & 70 & 100 \\ \text { Silvex } & 2 & 90 & 100 \\ \text { Haigler } & & & \\ \text { 2,4-D } & 1 / 2 & 90 & 100 \\ 2,4-\mathrm{D} & 1 & 90 & 100 \\ \text { 2,4-D } & 2 & 90 & 100 \\ \text { 2,4-D+2,4,5-T } & 1+1 & 90 & 100 \\ 2,4,5-\mathrm{T} & 1 / 2 & 85 & 100 \\ 2,4,5-\mathrm{T} & 1 & 85 & 100 \\ 2,4,5-\mathrm{T} & 2 & 85 & 100\end{array}$

Haigler, there was no regrowth of sand sagebrush two years after repeat applications with any of the chemicals. Table 2 gives final evaluations of the control for single and repeat treatments. Single herbicide treatments at Haigler gave better control than at Alliance. Excellent control was obtained with repeat applications of all herbicides at Alliance and Haigler except $1 / 2 \mathrm{lb} / \mathrm{A}$ of 2,4-D at Alliance. One $1 \mathrm{~b} / \mathrm{A}$ of 2,4-D applied two consecutive
2,4-D + water + surfactant at 2 gpa

52

2,4-D + water + surfactant at 2 gpa

2,4-D + No. 2 diesel oil at 2 gpa

2,4-D + water at 5 gpa

2,4-D + water + surfactant at 5 gpa

2,4-D + No. 2 diesel oil at 5 gpa

Haigler

2,4-D + water at 2 gpa

2,4-D + water + surfactant at 2 gpa

2,4-D + No. 2 diesel oil at 2 gpa

$2,4-\mathrm{D}+$ water at $5 \mathrm{gpa}$

2,4-D + water + surfactant at 5 gpa

$2,4-\mathrm{D}+$ No. 2 diesel oil at 5 gpa years at Alliance and Haigler gave 95 and 100 percent control, respectively.

The proper spray volume per acre for effective woody plant control by aerial application has not been fully explored. The volume depends upon several factors, including the method of herbicide application, species, and density of the vegetation. Darrow (1956) stated that volume spray rates for brush control by aircraft are commonly four to five gallons per acre. Hansen (1952) reported that as a general rule, low volume-high concentration treatments of phenoxy chemicals have been considerably less effective than the high volume-low concentration. However, aerial applications using five gallons or less per acre of a concentrated solution have been effective in most situations.

In this study, there were no significant differences between 2 and 5 gpa spray volumes at Alliance and Haigler when used in combination with 1 lb/A 2,4-D for control of sand sagebrush (Table 3). Also, there were no differences in number 2 diesel fuel, water, or water plus surfactant carrires in combination with $1 \mathrm{lb} / \mathrm{A} 2,4-\mathrm{D}$. The regrowth after repeat application was substantially higher at Alliance

Table 3. Regrowth and top kill of sand sagebrush one year after single and repeat applications of $1 \mathrm{lb} / \mathrm{A}$ 2,4-D in diesel oil, water, and water plus surfactant at spray volumes of 2 and 5 gpa.
Location, Regrowth Top kill

herbicide, and carrier Single Repeat Single Repeat

Alliance

$-\ldots-($ Percent $)$

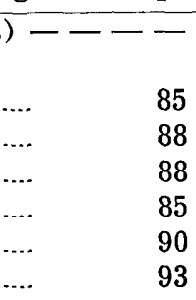

\section{2}

35

35

35

40

35
85

88

88

90

93 
than in other years. Close examination revealed that regrowth in the treated plots was very small in proportion to total plant material, although the total number of plants showing regrowth might be high. It is questionable whether many of these plants will survive. The plants that do survive will require several years to regain competitive vigor against desirable forage species (Figure 1, bottom). Estimated control based on top kill of sand sagebrush at Alliance and Haigler is given in Table 3. A single application at Haigler gave as good or better control than the repeat treatment at Alliance.

Excellent control of sand sagebrush was obtained in a study in which silvex was applied by airplane (Table 4). A single application of $1 \mathrm{lb} / \mathrm{A}$ silvex was the only treatment showing any regrowth two years later. A single application of $2 \mathrm{lb} / \mathrm{A}$ silvex appeared to be very effective. No differences were noted in control due to herbicide carrier or spray volume.

\section{Summary and Conclusions}

Single and repeat aerial applications of 2,4-D;2,4,5-T; a $1: 1$ mixture of $2,4-\mathrm{D}$ and $2,4,5-\mathrm{T}$; and

Table 4. Initial leaf kill and subsequent regrowth of sand sagebrush after single and repeat applications of silvex at Angora, Nebraska.

\begin{tabular}{|c|c|c|c|c|c|c|c|}
\hline \multirow{4}{*}{$\begin{array}{l}\text { Year applied, } \\
\text { herbicide, and carrier }\end{array}$} & \multicolumn{7}{|c|}{ Time after application } \\
\hline & \multicolumn{5}{|c|}{ Single } & \multicolumn{2}{|c|}{ Repeat } \\
\hline & & Leaf ki & & Regrc & & Regr & owth \\
\hline & $\mathrm{Lb} / \mathrm{A}$ & $3 \mathrm{mo}$. & $1 \mathrm{yr}$. & $2 \mathrm{yl}$ & 3 yr. & - $1 \mathrm{yr}$. & $2 \mathrm{yr}$. \\
\hline 1960 & & & 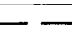 & $(\mathrm{Pe}$ & ent) & -- & - \\
\hline Silvex + No. & 1 & 100 & 0 & 1 & 22 & 0 & 10 \\
\hline Silvex & 2 & 100 & 0 & 0 & 0 & 0 & 0 \\
\hline $\begin{array}{l}\text { Silvex }+ \text { No. } 2 \text { diesel oil at } 5 \text { gpa } \\
1961\end{array}$ & 4 & 100 & 0 & 0 & 0 & 0 & 0 \\
\hline Silvex + water at 2 gpa & 2 & ...... & 5 & .. & $\cdots$. & $\cdots$ & $\cdots$ \\
\hline Silvex + water + surfactant & 2 & $\ldots$. & 5 & .. & $\ldots$. & 0 & .... \\
\hline Silvex + No. 2 diesel oil at 2 gpa & 2 & ...... & 5 & .. & $\ldots$. & 0 & $\ldots$. \\
\hline Silvex + water at 5 gpa & 2 & ...... & 5 & .. & $\ldots$. & 0 & .... \\
\hline Silvex + water + surfactant at 5 gpa & 2 & ....... & 5 & $\cdots$ & $\ldots$. & 0 & $\ldots$. \\
\hline Silvex + No. 2 diesel oil at 5 gpa & 2 & ...... & 5 & .. & $\cdots$. & 0 & $\cdots \cdot$ \\
\hline
\end{tabular}

silvex were applied for sand sagebrush control in western $\mathrm{Ne}$ braska. Single applications of the phenoxy herbicides gave excellent control at some locations. Repeat applications were necessary for best results to kill regrowth the year following initial treatment with 2,4-D and/or 2,4,5-T. Silvex consistently gave excellent control from a single application at the rates used.

One $\mathrm{lb} / \mathrm{A} 2,4-\mathrm{D}$ and $2 \mathrm{lb} / \mathrm{A}$ silvex were applied in combination with number 2 diesel fuel, water, and water plus surfactant carriers. Two and 5 gpa spray volumes were used with all carrier combinations. Results indicate there were no differences in sand sagebrush control due to carriers or spray volume.

\section{LITERATURE CITED}

DARrow, R. A. 1956. Aerial application of herbicides in brush and wed control. Handbook on Aerial Application in Agr. A \& M College of Texas. $145 \mathrm{pp}$.

Hansen, H. L. 1952. Control of woody plants (summary) NCWCC Res. Rpt. 165 pp.

KLINGMAN, D. L. 1962. An untapped market-weed control on grazing lands. Farm Chemicals. 124: 12-14.

McIlvain, E. H., A. K. BaKeR, W. R. KneEbone and D. H. Gates 1955. Nineteen-year Summary of Range Improvement Studies at the U. S. Southern Great Plains Field Station. USDA. $33 \mathrm{pp}$.

Shafer, N. E. 1951. Aerial spraying progress report. Agronomy Dept. Circ. 99. University of Nebr. 13 pp.

Shafer, N. E. 1955. Farming from the air. Research Report. University of Nebraska. 6:5-10.

SHAFER, N. E. 1960. Agricultural aircraft equipment. Nebr. Agr. Expt. Sta. Circ. 104. 15 pp. 